\title{
Entomophagy and Public Health: A Review of Microbiological Hazards
}

\author{
Pauline Kooh1, Ermolaos Ververis ${ }^{2,3}$, Vincent Tesson ${ }^{4}$, Géraldine Boué ${ }^{4}$, Michel Federighi ${ }^{4}$ \\ ${ }^{1}$ French Agency for Food, Environmental and Occupational Health \& Safety, Risk Assessment Department, Maisons-Alfort, France \\ ${ }^{2}$ School of Medicine, National and Kapodistrian University of Athens (NKUA), Athens, Greece \\ ${ }^{3}$ European Food Safety Authority, Parma, Italy \\ ${ }^{4}$ Oniris, UMR 1014 SECALIM INRA/Oniris, Nantes, France \\ Email: ^michel.federighi@oniris-nantes.fr
}

How to cite this paper: Kooh, P., Ververis, E., Tesson, V., Boué, G. and Federighi, M. (2019) Entomophagy and Public Health: A Review of Microbiological Hazards. Health, 11, 1272-1290.

https://doi.org/10.4236/health.2019.1110098

Received: August 17, 2019

Accepted: October 11, 2019

Published: October 14, 2019

Copyright (c) 2019 by author(s) and Scientific Research Publishing Inc. This work is licensed under the Creative Commons Attribution International License (CC BY 4.0).

http://creativecommons.org/licenses/by/4.0/

(c) (i) Open Access

\begin{abstract}
The world population's constant increase and the continuous need to ensure food safety and security are among the major challenges to be faced in the next 30 years. In addition, human diet is evolving with a decreased inclusion of proteins from animal sources. In this context, consumption of insects by humans (entomophagy) could be an alternative solution to the intake of protein derived from conventional livestock, due to the lower environmental impact of insect rearing compared to traditional farming. Furthermore, various insect species have promising nutritional profiles regarding both macro and micronutrients. Nowadays, it is recognized that about 2 billion people consume insects at a worldwide scale, with more than 2000 different species to have been reported. Since the beginning of the 2000s, mass rearing of insects for human consumption has been developing all over the world. Nevertheless edible insects are foodstuffs of animal origin and are usually consumed in their entirety, including the digestive tract, meaning that they may contain biological agents with hazardous potential (e.g. bacteria, parasites, viruses, prions, yeasts, molds, mycotoxins, histamine, and antibiotic resistance genes) and they must undergo a thorough analysis. Therefore, establishing the synthesis of the current knowledge on entomophagy and the related biological hazards is the main purpose of this review.
\end{abstract}

\section{Keywords}

Entomophagy, Microbial Hazards, Public Health, Food Safety

\section{Introduction}

The future of food in the next decades will be highly influenced by the popula- 
tion growth, the need to ensure sustainable food safety and food security and consumer trends like the decrease of intake of proteins from animal sources. The current model of production of animal proteins, mainly from cattle, swine, poultry and fish has been shown to have limitations and negative impacts on the environment. In this context, consumption of insects by humans (entomophagy) could be an alternative solution as insects appear to be a still under-exploited food source [1] [2] [3]. In fact, this relatively "new" source of animal proteins for western countries appears to have promising nutritional values and requires, for example, two to ten times less agricultural lands to produce one kilogram of insect protein compared to the production of one kilogram of protein from pigs or cattle, respectively [4] [5]. Nowadays, it is recognized that about 2 billion people consume insects in the world with more than 2000 different species to have been reported [3]. In some countries, insects are a culturally highly desirable food, especially in the tropics [6]. In other countries, particularly in occident, entomophagy is not yet fully accepted, neither culturally nor socially [7] [8]. At this stage, it is obviously necessary to differentiate between occasional or even personal insect consumption with consumption at the population level, which requires the development of mass rearing to produce animal proteins rapidly, at a lower cost and with a lower environmental impact [5].

This industrialization phase of production is underway in several developed countries, including some belonging to the European Union (e.g. the Netherlands, France, and Belgium). Careful choice of the insect species to be reared among the existing ones has to be done, in order to ensure the sustainability and profitability of these farms [8]. For mass rearing, the main criteria of choice are: the nutritional profile of the insect species, a high rate of reproduction and synchronization of nymphosies, an adapted ethology (no cannibalism) and great ease of handling with insects small in size that should not fly or jump when possible [9]. They must also have a high feed conversion rate (i.e. biomass gain per kg feedstock), with inexpensive but non-waste feed [10] [11] [12]. Once the choice is made, zootechnical parameters for rearing are adapted and controlled (temperature and ventilation of the premises, circadian rhythm or not, lighting...) [10].

Foods contaminated by biological or chemical hazards can cause outbreaks or sporadic cases in consumers. Thus, in many countries, foodstuffs are subject to various regulations and monitoring of their production conditions [13]. As such, it is very important to be able to quantify the relative contributions of different sources to the human disease burden; it is the role of source attribution studies that are currently developed [14]. In fact, several studies have shown in recent years, all over the world, that food of animal origin was responsible for more than 50\% of reported food-borne infectious diseases outbreaks [15] [16] [17] [18]. If, in the coming years in industrialized countries, insects are to become an increasing part of the population's diet, it is crucial to identify and analyze biological hazards (e.g. bacteria, parasites, viruses, prions, yeasts, molds, mycotoxins, 
histamine, antibiotic resistance genes) likely to be transmitted, especially since insects are generally consumed, or used for the manufacture of powders, whole, with their digestive tract [19]. This is the main objective of this review.

\section{Parasites}

It is well known that insects can carry specific internal and external parasites, which can cause diseases to insects. For example, it has been reported that nematodes belonging to the genera Steinernema and Heterorhabditis, can negatively affect Acheta domesticus [20], while Spinochordodes tellinni causes high mortality in crickets and grasshoppers [21]. Insects can also be intermediate or accidental hosts, or even simple vectors, as in the case of Trypanosoma and Leishmania transmission [22] [23].

The transmission of parasites to humans through the consumption of insects was for instance illustrated by [24], who studied the occurrence of intestinal flukes in Southeast Asia. Among the parasite species discussed in the study with the potential to infect humans, around $10 \%(6 / 65)$ of the species had as a host larvae or nymphs of aquatic odonates insects (e.g. dragonfly, damselfly):

- Phaneropsolus bonnei in naiads of dragonfly, in damselfly;

- Prosthodendrium molenkampi: in naiads of dragonfly, in damselfly;

- and 4 species of Plagiorchis (harinasutai, javensis, muris and philippinensis) in insect larva, naiads, nymphs...

Metacercariae of these parasites, known to cause intestinal parasitosis in humans, have been identified in these odonates in Thailand, Indonesia or Laos. The authors linked the cases of human intestinal infection by these flukes to the consumption of the aforementioned insects, since these insect species are consumed in these countries. Regarding Plagiorchis philippinensis, transmission to humans through the consumption of insect larvae has been proven [25].

The case of Gongylonema pulchrum, parasite of the esophagus and mouth, is of particular interest, since some insect species can act as mandatory intermediate host, the final host being most often livestock (domestic cattle). Humans are accidental host by consuming the intermediate host. Following consumption (voluntary or not) of raw insects, patients with nausea and vomiting describe the "Zigzagging" sensation in the mouth or throat [26]. Several cases have been reported in the United States [26] [27].

The consumption of insects (ants) containing metacercariae of Dicrocoelium dendriticum led to dicrocoeliasis in humans. Generally, this food-borne zoonosis is caused by consumption of bovine or mainly ovine contaminated meats [28].

Regarding the main parasites of interest when assessing the microbiological safety of food or water, the bibliography is scanty, probably showing a certain species barrier. However, some protozoa such as Entamoeba histolytica and Giardia lamblia have been isolated from some species of cockroaches. These insects may also carry Toxoplasma sp. and Sarcocystis sp. In some Diptera, various protozoa potentially dangerous to human health have been very rarely isolated (Tox- 
oplasma gondii, Sarcocystis sp., Isospora sp., Giardia sp., and Cryptosporidium sp.) [29].

\section{Viruses \& Prions}

\subsection{Viruses}

Like parasites, there are many entomopathogenic viruses specific for invertebrates that cause Animal Health problems, but their presence and virulence in vertebrates have never been described [30]. The most well-known are the Densoviruses (AdDV) and the Cricket Paralysis Virus (CrPV), with the latest to cause particularly high mortality rates for A. domesticus populations [19]. These viruses are a severe problem in mass rearing for the production of food for humans or animals [12]. Notwithstanding, some of these viruses belong to families taxonomically related to human viruses (Iridoviridae, Parvoviridae, Iflaviridae, Dicistroviridae and Reoviridae), and the question of a possible crossing of the vertebrate/invertebrate border would require to be further investigated. Tests carried out with Densovirus (AdDV) did not lead to multiplication of this virus on vertebrate cells cultures, suggesting that, in that case, this border is efficient [31].

Nevertheless, in some cases, insects allow the multiplication and transmission of viruses to humans or livestock, as active viral vectors [12]. Such is the case of Arboviruses (Arthropod-born viruses) which are responsible among others for manifestations of Dengue fever, Chikungunya disease, and West Nile disease in humans and manifestations of Schmallenberg virus disease in cattle. In fact, these viruses multiply both in vertebrates and invertebrates (mosquitos, ticks). However, mosquitos and ticks are not considered as edible insects and, to date, detection of such viruses in edible insects have not be done yet.

Insects can also transmit vertebrate viruses, with an example being the transmission of H5N1 influenza virus to chickens via infected flies, under experimental conditions [32]. The ability of some viruses to maintain infectivity, for several days, in different matrices, including manure, should draw attention to the use of such animal materials as a substrate for insect rearing [11]. It should be noted that in the European Union the use of waste for the rearing of farmed animals is forbidden. Regarding foodborne viruses of main concern, such as norovirus, rotavirus and Hepatitis virus [17], there is a lack of information on their possible transmission via consumption of insects. In addition, cooking practices and processing methods (e.g. boiling, frying, drying...) can potentially mitigate the risk of transmission [12].

\subsection{Prions}

So far, the existence of prion or prion-related protein encoding genes in insects has not been reported, meaning also that insects lack the potential to act as biological vectors and amplifiers of animal/human prions [12] [19] [33]. Nevertheless, it has been demonstrated that some insect species can act as mechanical 
vectors of prions that are present in the rearing substrate, as highlighted for scrapie in sheeps [34]. Reference [19] summarized studies that report the high stability of prions in the environment, and the prions' ability to maintain their infectivity for long timespan in soil and water. Use of substrates of non-human and non-ruminant origin [12], as well as control of the substrate's quality and feed quality [19] could act as preventive measures to avoid occurrence of prions in the edible insects.

\section{Fungi (Yeasts, Molds-Mycotoxins Thereof)}

It is know that several hundred species of entomopathogenic fungi, often with host specificity, cause significant mortality rates among farmed insect populations [30]. Few studies are available on the contamination of edible insects with yeasts and molds pertinent to food safety. Quantitative levels of these microorganisms serve as hygiene indicators during the manufacturing process of insect-based foodstuffs, usually with no further identification of species or genera. Samples (insect powder or insects) with levels of yeast and molds around $10^{4}$ $\mathrm{cfu} / \mathrm{g}$ of powder or insects are not uncommon [35]. Generally, yeasts are not the dominant flora, despite [36] recently demonstrated the presence of Trichosporon asahii, an opportunistic pathogenic yeast that causes superficial skin infections in immunocompromised individuals, in edible insects. Reference [37] detected Debaryomyces hansenii in dried Tenebrio molitor larvae produced in Belgium and the Netherlands.

In an exhaustive review [35], it has been reported that different fungal species were detected on mopane worm (Imbrasia belina) in the 90s [38] [39]. Aspergillus, Penicillium, Fusarium, Cladosporium and Phycomycetes were found both in the gastrointestinal tract of fresh insects and in whole dried insects [40]. Cladosporium and Fusarium are food contaminants with fast growing rates, with the ability to deteriorate the product quickly if it is not dehydrated, and to produce certain mycotoxins. Ubiquity and ability of Aspergillus and Penicillum species to grow even on substrates with low moisture content highlight the need to monitor the levels of these species post-treatment [41]. For example, Aspergillus flavus is known to produce aflatoxins, with carcinogenic, mutagenic and teratogenic potential in animals and humans. More recently, several studies have detected species of mycotoxin-producing molds in such as:

- Aspergillus niger and Aspergillus flavus/parasiticus (aflatoxin producers);

- Aspergillus ochraceus (ochratoxin producer);

- Penicillium citrinum (citrinin producer);

- Penicillium verrucosum (citrinin and ochratoxin producer). Others insects than mopane worms can harbor these molds:

- A. niger was detected in Bunae alcinoe and pallid emperor moth (lepidopters), Oryctes monoceros and Rynchophorus phoenicis (coleopters);

- A. flavus was detected in Macrotermes bellicosus (isopter), Rynchophorus phoenicis and Alphitobius diaperinus (coleopters). 
Other Aspergillus species (cristatus, chevalieri and intermedius) were isolated from Buyus domesticus purchased in the Netherlands [37]. It is important to note that the presence of toxigenic molds does not necessarily mean the presence of mycotoxin in products, especially in insect powders. Conditions for mycotoxinogenesis are not always present in insects, although it is known that it is possible, as discussed by [39] in mopane worms from 12 different locations in Botswana. Seven of the twelve samples had higher aflatoxin concentrations, up to $50 \mu \mathrm{g}$ per $\mathrm{kg}$, than the tolerable dose of $20 \mu \mathrm{g}$ per kg [39] [42]. Recently, [43] have shown that mycotoxins added in rearing substrate can contaminate lesser mealworms and black soldier fly.

\section{Bacteria (and Their Toxins), Histamine and Other Concerns}

Once again, several authors wrote that entomopathogen bacteria are not pathogen for human because they are phyllogenetically far from human pathogens [3] [12] [30]. Generally speaking this could be true, but some studies bring some nuances to that truism. For example, Klebsiella pneumoniae, an opportunistic human pathogen occurs frequently in intestinal tract of oriental migratory locust [44]. Spiroplasma sp., a well known insect pathogens, can cause neurodegenerative diseases in humans and animals. Systemic infection in a human by Spiroplasma sp. has also been reported [45] [46]. Wohlfahrtiimonas chitiniclastica (a fly pathogen) caused a fulminant sepsis in a 70-year-old man in Argentina [47]. The case of $B$. thuringiensis (BT) is very interesting too because of production of intracellular protein crystals, which are toxic for a large amount of insect larva and it's used in biological control of insect pest. Nevertheless, recently, role of BT in food borne disease is alleged [48].

Biological hazards likely to be transmitted during the consumption of insects are [3]:

- related to the intrinsic microflora of insects (digestive tract and other anatomical compartments);

- related to extrinsic origin from the environment and rearing conditions.

The biological risk assessment related to the consumption of insects requires a further insight into the probability of transmission of the main foodborne bacterial pathogens (spore forming and non-spore forming). In several studies, various hygiene indicators of insects rearing and insect products thereof have been investigated, in order to evaluate the impact of processing steps (e.g. fasting, heating, freezing, drying, frying...) on the microbiological status of the final product. All these different points will be further discussed below.

\subsection{Hygiene Indicators}

One of the first microbiological indicators used is the Total Mesophilic Aerobes (TMA) or Total Aerobic Count (TAC) that gives information on the total aerobic microbial load of the under-analysis product. Current literature indicates 
that the microbial loads of insect-based foodstuffs are generally high, with the presence of the gastrointestinal tract. Reported TAC values for crickets ranged from $10^{1}$ to $8.9 \times 10^{8} \mathrm{cfu} / \mathrm{g}$ according to type of insect product analyzed, (hard processed or fresh), respectively [49] [50]. A fasting step of $24-48 \mathrm{~h}$ is usually implemented before insect slaughtering, in order to allow the insects to empty their bowel content and decrease the total microbial load. However, the efficiency of this measure has not been clearly demonstrated yet [19]. Microbiological criteria (hygiene or safety) for insects and products thereof as food at a European Union level do not exist yet. Nevertheless, for instance, the competent authorities of the Netherlands and Belgium, have already proposed $6 \mathrm{log} \mathrm{cfu} / \mathrm{g}$ of lyophilized insects and 5.7 to $6.7 \mathrm{log} \mathrm{cfu} / \mathrm{g}$, respectively, as hygiene criteria [51] [52].

Lactic Acid Bacteria (LAB) and Enterobacteriaceae are the two other indicators discussed in several studies. LAB is a large group of Gram-positive aero-anaerobic bacteria involved in fermentation process. They are generally not pathogenic for human but they can cause spoilage of many foods, including edible insects [53] [35]. High counts of LAB in unfermented products could be a sign of a malfunction of the production process and deviation from the hygiene procedures. For example, in red meat industries the ratio LAB/TAC (number of Lactic Acid Bacteria on number of Total Aerobic Count) has to be around $10^{-2}$. If the ratio is near 1, Quality Management Programs (QMP) have to be checked, and the products are retained [54].

Enterobacteriaceae is a group of Gram-negative bacteria whose main reservoir is the digestive tract of humans and warm-blooded animals. Enterobacteriaceae are sometimes detected in edible insects, especially in insects collected from the wild [55]. However, their presence in products is a sign of poorly hygiene. Since a simple heating step is sufficient to reduce number of Enterobacteriaceae, their presence after such a step is a sign of re-contamination of fecal origin and/or handling error [53]. In Netherlands a threshold of $10^{3} \mathrm{cfu} / \mathrm{g}$ of Enterobacteriaceae has been recommended for edible insects [56].

In addition, these biological indicators are used to evaluate the microbicidal efficacy of specifics production steps, namely fasting period, boiling, freezing, drying, frying, grinding, packaging and storage [49] [57]. Not surprisingly, it appears that heat treatments (boiling better than frying or heat drying) permit drastic reduction of load of vegetative cells, specially, but not only, Enterobacteriaceae [35] [58]. Reference [58] has compared TAC reduction (Total Aerobic Count) of Tenebrio molitor larvae after:

- 10 min at $90^{\circ} \mathrm{C}$ and $45^{\circ} \mathrm{C}$ (boiling);

- $10 \mathrm{~min}$ at $600 \mathrm{MPa}$ (high hydrostatic pressure);

- $10 \mathrm{~min}$ at $90^{\circ} \mathrm{C}$ (dry oven).

The most efficient TAC reduction of larvae was obtained after boiling at $90^{\circ} \mathrm{C}$ (4 logs) and after High Hydrostatic Pressure treatment (3 logs). Treatment for ten minutes at $90^{\circ} \mathrm{C}$ in a dry oven or at $45^{\circ} \mathrm{C}$ in water achieved the same result: around $1 \log$ reduction [58]. 


\subsection{Histamine}

Histamine, a heat stable toxin, is a metabolite resulting from the decarboxylation of histidine. A recent outbreak investigation that occurred in 2014 in Thailand was described by [59]. During a seminar, 41 students amongst 227 bring snacks for dinner. Snacks, from a unique vendor in vicinity, were fried grasshoppers, silkworm pupae and green frogs fried as well as crickets and meatballs. Among the 41 students who consumed the snacks, 28 developed symptoms with: flushing, pruritus, urticarial rashes, headache, nausea and vomiting, two were hospitalized. The attack rates were highest ( $82.6 \%$ and $85 \%)$ among students who ingested fried grasshoppers and silkworm pupae and lowest (4.4\% and 5.3\%) among those who did not consume them (RR of 18.7 at 95\% CI). The authors postulated that histidine, found in high levels in grasshoppers and silkworm pupae, was converted to histamine via decarboxylation by the bacterial populations present in insects, during storage. Since histamine is heat stable, it was not eliminated during frying, leading to the observed clinical outbreaks [59].

\subsection{Non Spore Forming and Spore Forming Bacteria}

In Europe, the main food-borne bacterial pathogens are Campylobacter sp., Salmonella, STEC (Shiga Toxin E. coli), L. monocytogenes, C. perfringens (and botulinum), $S$. aureus, B. cereus group, Yersinia sp. Outside Europe, it would be necessary to add Vibrio sp. to these bacteria. This list contains both non spore forming and spore forming bacteria (such as Clostridium and Bacillus), which are resistant to a wide range of stress conditions related to environment or industrial processes.

In the last few years, several studies have been conducted to analyze further this list of aforementioned microorganisms, with regard to farmed insects and products thereof, and in order to better know if these bacteria are only potential or significant hazards [49] [57] [60]-[68].

Concerning Campylobacter jejuni/coli and STEC (E. coli O157:H7) it seems that insects are not a primary reservoir for these bacteria. Nevertheless, precedent studies have shown that arthropods, like flies, can be a vector of dissemination of Campylobacter in poultry production [69], and a vector of amplification for $E$. coli O157:H7 [70]. Campylobacter genera have been already identified in edible insects [63]. More recently, [71] identified OTUs (Operational Taxonomic Unit) with a high $16 \mathrm{~S}$ rRNA similarity with Campylobacter rectus and Campylobacter concisus. Despite this, it seems that Campylobacter jejuni/coli and E. coli O157:H7 are not of critical concerns [34]. Even Yersinia enterocolitica does not seem to be a critical concern for edible insects for [36].

Regarding Vibrio sp., its presence in edible insects is very rare. Only $V$. hangzhouensis and $V$. diazotrophicus, which are not pathogenic, have been detected in processed giant water bug [67]. Thus, Vibrio sp. is not considered as a safety concern with regard to edible insects [35].

To our knowledge, Listeria monocytogenes has not been isolated yet from ed- 
ible insects by cultural method. Furthermore, processed insects are unable to support the growth of L. monocytogenes [68]. Despite this, [65] have detected Listeria spp. in cricket powder and processed mealworm, then [68] have isolated Listeria sp. from salted mealworm by MPN method. These authors found that the species L. monocytogenes is not a critical hazard in edible insects but they recommended further studying.

Regarding Salmonella, an important foodborne pathogen, several studies have shown absence in $25 \mathrm{~g}$ samples of fresh and processed edible insects [65] [61] [67] [68]. Reference [35] indicates in their review that Salmonella has been occasionally detected in tenebrionid beetles, flies, cockroaches [38] [72]. In his review it has been reported that only [73] isolated Salmonella from fresh and fried grasshoppers in the North of Cameroon. Notwithstanding, this bacteria is still a major concern since [74] have shown that Salmonella can survive in the substrate used during rearing of mealworms and can been further transmitted to the larvae.

Concerning Clostridium, as far as we know, detection of C. botulinum in edible insects has not been reported yet, although Clostridium spp. have been reported in fresh Tenebrio molitor, processed whole crickets and grasshoppers [60] [66] [71]. Reference [63] reports that spores of $C$. perfringens have been counted in processed (boiled and dried) whole crickets, grasshoppers and mealworms as well as in cricket powder. The results were around $2 \log \mathrm{cfu} / \mathrm{g}$, which is under the ID50 (Infectious Dose) for C. perfringens. It is important, however, to draw attention to the conservation conditions of processed insects which should not favor the increase in $C$. perfringens cells. For [75] rehydration and use of $C$. perfringens contaminated insect powders in other preparations (e.g. baby porridge) is a potential risky practice.

Regarding Staphylococcus aureus, it seems that the genera Staphylococcus is very abundant in the microflora of numerous edible insects [35] [37] [76] [77] [78]. Identification at the species level has not been done in all cases but sometimes $S$. aureus has been detected in fresh and processed insects [61]. When species-level identification is done there is no information on the enterotoxigenic ability of the strain, as far as we know. Presence of $S$. aureus is due to his omnipresence in nature, frequent human carriage and/or processing error. Staphylococcus aureus is sensitive to heat but is also halophilic and resistant to low Aw, its toxin is heat-resistant. Physico-chemical properties of insect's powders are compatible with survival or growth of $S$. aureus. Many authors believe that with respect to this hazard, without overestimating it, we must remain vigilant, especially when taking into consideration the conditions of production and conservation of edible insects and products thereof.

Concerning Bacillus cereus group and other Bacillus sp., it seems that they are freqently detected in numerous fresh and processed edible insects, wild or reared [35]. Particularly, two studies have focused on $B$. cereus group, with quantitative data on edible insects (mealworms, crickets and silkworms) [37] [68]. B. cereus 
counts of 4 to 6.6 logs cfu/g have been found by [68] while, [37] reported B. cereus counts of around 5 logs cfu/g in marketed cricket powder. Such counts are compatible with the Toxic Dose of B. cereus [75]. Once again, presence of high number of cells doesn't mean that $B$. cereus heat stable toxin (cereulid) is present. Emetic syndrome caused by cereulid toxin of $B$. cereus needs toxinogenesis in the food. Fresh or processed edible insects are not the ideal substrate for this toxinogenesis. Notwithstanding, B. cereus spores are capable to survive during very long period of time in insect powders. Several authors draw attention to the risk for consumers when rehydrated insect products. Due to its abundance in soils and insects, and due to its resistance to industrial treatments and other stress, B. cereus group is a major concern in consumption of edible insects [68].

\subsection{Others Concerns}

In addition to these major food-borne pathogens, other publications draw attention to less common (Cronobacter) and/or non-foodborne (Pseudomonas) pathogens. Recently, two studies focused on the dissemination of antibiotic resistance genes through the microbiota of edible insects.

Concerning Cronobacter spp. (formerly known as the single species Enterobacter sakazakii), it's a Gram-negative rod shaped bacteria present in different environment, causing bacteraemia, meningitis and necrotizing enterocolitis especially in babies via the consumption of infant formula [75]. These bacteria can survive in very dry media, it have been detected in dry foods, industrial environment and in edible insects [63] [66]. Reference [75] have pointed out the potential risk using cricket powder, which have texture and physico-chemical properties similar to infant formula, for enrich the nutritional quality of children porridge in Cambodia. The authors concluded that Cronobacter spp. (and C. sakazakii) risks in insect powders have to be evaluated more thoroughly.

Reference [35] pointed out that Pseudomonas sp. and P. aeruginosa are present in several habitats (soil, water, plants...) and have been regularly detected in edible insects [76] [79] [80] [81]. P. aeruginosa, a strictly aerobic Gram-negative bacillus, is considered as an opportunistic pathogen involved in many nosocomial infections, with the ability to contaminate humans via multiple routes (eye, wounds, urinary tract, mouth...). Food is a potential dissemination medium for Pseudomonas aeruginosa, which is sensitive to moderate heat treatment and its presence in edible insects can be therefore controlled by practices such as boiling and heat drying. Nevertheless, it is also known to be very difficult to treat because it is resistant to disinfectants and antibiotics, and can thus participate in the dissemination of resistance genes [82].

Dissemination of antibiotic resistance genes is not a microbiological hazard sensu stricto; it's an indirect hazard coming from microorganisms. Antibiotic resistance is an emerging threat to public health and microbiota of foods has a significant role to that. The use of antibiotics in edible insects rearing is an under-investigated field. In case of emergency, treatments to eradicate entomopathogen sensitive agent from rearing site are possible, alongside implementation 
of others cleaning procedures, in order to save some adults for reproduction [30]. On the other hand, edible insects reared on manure may be exposed predominantly to veterinary drug residues and also to fecal bacteria that may have antibiotic resistance genes [56]. A recent study failed to show the bioaccumulation of antibiotic residues in larvae of black soldier flies reared on a substrate containing them [56], other recent studies have focused on potential detection of antibiotic resistance genes in insect samples [82] [83] [84] [85] [86]. It is known now that genes resistance to tetracycline, erythromycin and $\beta$-lactams can been detected in edible insects' samples with more or less high frequencies depending on the type of insects and their geographical origin. Rearing practices may also have a role in its frequencies (use of antibiotics, quality of feed for insects rearing, quality of substrate use for rearing). These authors agree to say that this phenomenon deserves a thorough evaluation in the coming years [35].

\section{Conclusions}

The consumption of insects has always been a widespread social and cultural practice in tropical countries [87]. Today, this practice seems to gradually gain the interest of the western world. Insect-derived proteins could have in the next years a quite significant presence in the human diet [88]. Insect consumption could be beneficial from an environmental point of view, since insect rearing, compared to the farming of conventional livestock, requires the use of less agricultural land and water, and has a lower carbon footprint in total.

Insects (and products thereof) can then be perceived as a food of animal origin, with the particularity that insects are consumed with their digestive tract, which, in most cases, is not a natural reservoir for the main and well known foodborne microbiological hazards (e.g. Salmonella, Campylobacter, Listeria, etc.). However, in poorly controlled and hygienic rearing conditions, insects can be vectors of these microbiological hazards. Main sources of contamination of insects by these hazards are the rearing substrate (water, soil, litter, feed) and the human handling during farming. It is therefore very important to supervise the activities of mass rearing of insects with the contribution of good farming practices, and manufacturing and hygienic guidelines [89] [13]. These guidelines should be complemented by the establishment of a food safety assurance system using the principles of the HACCP method in the sites of mass production of insects [90]. For these reasons, production of insects for self-consumption at a personal level and consumption of insects collected from the wild, raw or cooked, shall not be encouraged [3] [12].

It is therefore crucial to be able to mass rearing edible insects in high hygienic conditions, with a steady control. But how to manage that? The question of establishing microbiological criteria (safety or hygiene) for edible insects is an important issue to address. Facing this matter with efficiency would require more quantitative data. Through the present work, it has been highlighted that several authors drew attention to use Total Aerobic Count and spore-forming bacteria 
count, as indicators of a proper management of the rearing process. We have also seen that $B$. cereus group (spore forming bacteria) could be a significant hazard related to consumption of processed insects, and that better knowledge of the microbial reduction effects of some key steps of the process is needed. It seems today that these particular points are the priorities for future studies on biological hazard related to the consumption of edible insects.

\section{Disclosures}

The positions and opinions presented in this article are those of the authors alone and are not intended to represent the views or scientific work of Agencies or Institutions. Ermolaos Ververis is employed with the European Food Safety Authority (EFSA) in the Nutrition Unit that provides scientific and administrative support to the Panel on Nutrition, Novel Foods and Food Allergens, in the area of Novel Foods. However, the present article is published under the sole responsibility of the authors and may not be considered as an EFSA scientific output. To learn about the views or scientific outputs of EFSA, please consult its website under http://www.efsa.europa.eu.

\section{Conflicts of Interest}

The authors declare no conflicts of interest regarding the publication of this paper.

\section{References}

[1] FAO (2009) How to Feed the World in 2050? http://www.fao.org/fileadmin/templates/wsfs/docs/expert_paper/How_to_Feed_the =World_in_2050.pdf

[2] Belluco, S., Losasso, C., Maggioletti, M., Alonzi, C.C., Paoletti, M.G. and Ricci, A. (2013) Edible Insects in a Food Safety and Nutritional Perspective: A Critical Review. Comprehensive Review of Food Science and Food Safety, 12, 296-313. https://doi.org/10.1111/1541-4337.12014

[3] Anses Opinion (2014) Opinion on the Use of Insects as Food and Feed and the Review of Scientific Knowledge on the Health Risks Related to the Consumption of Insects. https://www.anses.fr/fr/system/files/BIORISK2014sa0153.pdf

[4] De Vries, M. and de Boer, I.J.M. (2010) Comparing Environmental Impacts for Livestock Products: A Review of Life Cycle Assessments. Livestock Science, 128, 1-11. https://doi.org/10.1016/j.livsci.2009.11.007

[5] Oonincx, D.G.A.B. and de Boer, I.J.M. (2012) Environmental Impact of the Production of Mealworm as a Protein Source for Human-A Life Cycle Assessment. PLoS ONE, 7, e51145. https://doi.org/10.1371/journal.pone.0051145

[6] Van Huis, A. (2003) Insects as Food in Sub-Saharian Africa. Insect Science and Application, 23, 163-185. https://doi.org/10.1017/S1742758400023572

[7] Ramos-Elorduy, J. (2009) Anthropo-Entomophagy: Cultures, Evolution and Sustainability. Entomological Research, 39, 271-288. https://doi.org/10.1111/j.1748-5967.2009.00238.x

[8] Rumpold, B.A. and Schlüter, O.K. (2013) Potential and Challenges of Insects as an 
Innovative Source for Food and Feed Production. Innovative Food Science and Emerging Technology, 17, 1-11. https://doi.org/10.1016/j.ifset.2012.11.005

[9] Schabel, H.G. (2010) Forest Insects as Food: A Global Review. Proceedings of a Workshop on Asia-Pacific Resources and Their Potential for Development, Bangkok, 37-64.

[10] Rumpold, B.A. and Schlüter, O.K. (2013) Nutritional Composition and Safety Aspects of Edible Insects. Molecular Nutrition and Food Research, 57, 802-823. https://doi.org/10.1002/mnfr.201200735

[11] Lalander, C.H., Fidjeland, J., Diener, S., Eriksson, S. and Vinneras, B. (2015) High Waste-to-Biomass Conversion and Efficient Salmonella Reduction Using Black Soldier Fly for Waste Recycling. Agronomy for Sustainable Development, 35, 261-271. https://doi.org/10.1007/s13593-014-0235-4

[12] EFSA Opinion (2015) Risk Profile Related to Production and Consumption of Insects as Food and Feed. EFSA Journal, 13, e4257. https://doi.org/10.2903/j.efsa.2015.4257

[13] Federighi, M. and Friant-Perrot, M. (2009) Organizational and Operational Factors for Food Safety Management. In: Laude, A. and Tabuteau, D., Eds., Sécurité des patients, sécurité des consommateurs, Presse Universitaire de France, Paris, 147-159. https://doi.org/10.3917/puf.tabu.2009.01.0147

[14] Mughini-Gras, L., Kooh, P., Augustin, J.C., David, J., Fravalo, P., Guillier, L., Jourdan-Da-Silva, N., Thébault, A., Sanaa, M., Watier, L. and the Anses Working Group on Source Attribution of Foodborne Diseases (2018) Source Attribution of Foodborne Diseases: Potentialities, Hurdles and Future Expectations. Frontiers in $\mathrm{Mi}$ crobiology, 9, 1983. https://doi.org/10.3389/fmicb.2018.01983

[15] Greig, J.D. and Ravel, D. (2009) Analysis of Foodborne Outbreak Data Reported Internationally for Source Attribution. International Journal of Food Microbiology, 130, 77-87. https://doi.org/10.1016/j.ijfoodmicro.2008.12.031

[16] Painter, J.A., Hoekstra, R.M., Ayers, T., Tauxe, R.V., Braden, C.R., Angulo, F.J. and Griffin, P.M. (2013) Attribution of Foodborne Illnesses, Hospitalizations, and Deaths to Food Commodities by Using Outbreak Data, United States, 1998-2008. Emerging Infectious Diseases, 19, 407-415. https://doi.org/10.3201/eid1903.111866

[17] EFSA and ECDC (2018) The European Union Summary Report on Trends and Sources of Zoonoses, Zoonotic Agents and Food-Borne Outbreaks in 2017. EFSA Journal, 16, e05500. https://doi.org/10.2903/j.efsa.2018.5500

[18] Anses Opinion (2018) Opinion Related to Sources Attribution of Infectious Foodborne Diseases-Part 2: Epidemiological Data Analysis. https://www.anses.fr/fr/system/files/BIORISK2015SA0162Ra-2.pdf

[19] Fernandez-Cassi, X., Supeanu, A., Vaga, M., Jansson, A., Boqvist, S. and Vagsholm, I. (2019) The House Cricket (Acheta domesticus) as a Novel Food: A Risk Profile. Journal of Insects for Food and Feed, 5, 137-157. https://doi.org/10.3920/JIFF2018.0021

[20] Shapiro-Ilan, D.I., Mbata, G.N., Nguyen, K.B., Peat, S.M., Blackburn, D. and Adams, B.J. (2009) Characterization of Biocontrol Traits in the Entomopathogenic Nematode Heterorhabditis georgiana (Kesha Strain), and Phylogenetic Analysis of the Nematode's Symbiotic Bacteria. Biological Control, 51, 377-387. https://doi.org/10.1016/j.biocontrol.2009.07.009

[21] Libersat, F., Delago, A. and Gal, R. (2009) Manipulation of Host Behavior by Parasitic Insects and Insect Parasites. Annual Review of Entomology, 54, 189-207. https://doi.org/10.1146/annurev.ento.54.110807.090556 
[22] Pereira, K.S., Schmidt, F.L., Barbosa, R.L., Guaraldo, A.M., Franco, R.M., Dias, V.L. and Passos, L.A. (2010) Transmission of Chagas Disease (American Trypanosomiasis) by Food. Advances in Food and Nutrition Research, 59, 63-85. https://doi.org/10.1016/S1043-4526(10)59003-X

[23] Mézes, M. (2018) Food Safety Aspects of Insects: A Review. Acta Alimentaria, 47, 513-522. https://doi.org/10.1556/066.2018.47.4.15

[24] Chai, J.Y., Shin, E.H., Lee, S.H. and Rim, H.J. (2009) Foodborne Intestinal Flukes in Southeast Asia. Korean Journal of Parasitology, 47, S69-S102. https://doi.org/10.3347/kjp.2009.47.S.S69

[25] Yu, S.H. and Mott, K.E. (1994) Epidemiology and Morbidity of Food-Borne Intestinal Trematode Infections. Tropical Disease Bulletin, 91, R125-R152. https://apps.who.int/iris/bitstream/handle/10665/61103/WHO_SCHISTO_94.108.pdf

[26] Libertin, C.R., Reza, M., Peterson, J.M., Lewis, J. and Hata, D.J. (2017) Human Gongylonema pulchrum Infection: Esophaegal Symptoms and Need for Prolonged Albendazole Therapy. American Journal of Tropical Medicine and Hygiene, 96, 873-875. https://doi.org/10.4269/ajtmh.16-0852

[27] Wilson, M.E., Lorente, C.A., Allen, J.E. and Eberhard, M.L. (2001) Gongylonema Infection of the Mouth in a Resident of Cambridge, Massachusetts. Clinical Infectious Diseases, 32, 1378-1380. https://doi.org/10.1086/319991

[28] Jeandron, A., Rinaldi, L., Abdyldaieva, G., Usubalieva, J., Steinmann, P., Cringoli, G. and Utzinger, J. (2011) Human Infection with Dicrocoelium dendriticum in Kyrgiztan: The Tip of the Iceberg? Journal of Parasitology, 97, 1170-1172. https://doi.org/10.1645/GE-2828.1

[29] Graczyk, T.K., Knight, R. and Tamang, L. (2005) Mechanical Transmission of Human Protozoan Parasites by Insects. Clinical Microbiology Review, 18, 128-132. https://doi.org/10.1128/CMR.18.1.128-132.2005

[30] Eilenberg, J., Vlak, J.M., Nielsen-Leroux, C., Cappelloza, S. and Jensen, A.B. (2015) Diseases in Insects Produced for Food and Feed. Journal of Insects for Food and Feed, 1, 87-102. https://doi.org/10.3920/JIFF2014.0022

[31] El Far, M., Li, Y., Fédiére, G. and Tijssen, P. (2004) Lack of Infection of Vertebrate Cells by the Densovirus from the Maize Worm Mythimna loreyi. Virus Research, 99, 17-24. https://doi.org/10.1016/j.virusres.2003.09.010

[32] Wanaratana, S., Amonsin, A., Chaisingh, A., Panyim, S., Sasipreeyajan, J. and Pakpinyo, S. (2013) Experimental Assessment of Houseflies as Vectors in Avian Influenza Subtype H5N1 Transmission in Chickens. Avian Diseases, 57, 266-272. https://doi.org/10.1637/10347-090412-Reg.1

[33] Thackray, A.M., Muhammad, F., Zhang, C., Deneyer, M., Spiropoulos, J., Crowther, D.C. and Bujdoso, R. (2012) Prion-Induced Toxicity in PrP Transgenic Drosophila. Experimental and Molecular Patholology, 92, 194-201. https://doi.org/10.1016/j.yexmp.2012.01.005

[34] Post, K., Riesner, D., Waldorf, V. and Mehlhorn, H. (1999) Fly Larvae and Pupae Are Vectors for Scrapie. The Lancet, 354, 1969-1970. https://doi.org/10.1016/S0140-6736(99)00469-9

[35] Garofalo, C., Milanovic, V., Cardinali, F., Aquilanti, L., Clementi, F. and Osimani, A. (2019) Current Knowledge on the Microbiota of Edible Insects Intended for Human Consumption: A State-of-the-Art Review. Food Research International, 125, Article ID: 108527. https://doi.org/10.1016/j.foodres.2019.108527

[36] Wynants, E., Frooninckx, L., Van Miert, S., Geeraerd, A., Claes, J. and Van Campenhout, L. (2018) Microbial Dynamics Durind Production of Lesser Mealworms 
(Alphitobius diaperinus) for Human Consumption at Industrial Scale. Food Microbiology, 70, 181-191. https://doi.org/10.1016/j.fm.2017.09.012

[37] Osimani, A., Garofalo, C., Milanović, V., Cardinali, F., Aquilanti, L., Pasquini, M., Mozzon, M., Raffaelli, N., Ruschioni, S., Riolo, P., Isidoro, N. and Clementi, F. (2017) Insight into the Proximate Composition and Microbial Diversity of Edible Insects Marketed in the European Union. European Food Research Technology, 243, 1157-1171. https://doi.org/10.1007/s00217-016-2828-4

[38] Siame, A.B., Mpuchane, S., Gashe, B.A., Allotey, J. and Teferra, G. (1996) Nutritional Quality of Mophane Worms, Imbresia belina (Westwood), and the Microorganisms Associated with the Worms. Proceedings First Multidisplinary Symposium on Phanes, 18 June 1996, 80-83.

[39] Mpuchane, S., Taligoola, H. and Gashe, B. (1996) Fungi Associated with Imbrasia belina, an Edible Caterpillar. Botswana Notes and Records, 28, 193-197.

[40] Simpanya, M.F., Allotey, J. and Mpuchane, S.F. (2000) A Mycological Investigation of Phane, an Edible Caterpillar of an Emperor Moth, Imbrasia belina. Journal of Food Protection, 63, 137-140. https://doi.org/10.4315/0362-028X-63.1.137

[41] Pitt, J.I. (1995) Phylogeny in the Genus Penicillium: A Morphologist's Perspective. Canadian Journal of Botany, 73, 768-777. https://doi.org/10.1139/b95-321

[42] FAO/IAEA (2001) Manual on the Application of the HACCP System in Mycotoxin Prevention and Control. Training and Reference Centre for Food and Pesticide Control. FAO Food and Nutrition Paper 73, FAO, Roma.

http://www.fao.org/3/y1390e/y1390e00.htm

[43] Camenzuli, L., Van Dam, R., de Rijk, T., Andriessen, R., Van Schelt, J. and der Fels-Klerx, V. (2018) Tolerance and Excretion of the Mycotoxins Aflatoxin B1, Zearalenone, Deoxynivalenol, and Ochratoxin A by Alphitobius diaperinus and Hermetia illucens from Contaminated Substrates. Toxins, 10, 91. https://doi.org/10.3390/toxins10020091

[44] Su, L.J., Liu, H., Li, Y., Zhang, H.F., Chen, M., Gao, X.H., Wang, F.Q. and Song, A.D. (2014) Cellulolytic Activity and Structure of Symbiotic Bacteria in Locust Guts. Genetic Molecular Research, 13, 7926-7936.

https://doi.org/10.4238/2014.September.29.6

[45] Bastian, F.O., Elzer, P.H. and Wu, X. (2012) Spiroplasma spp. Biofilm Formation Is Instrumental for Their Role in the Pathogenesis of Plant, Insect and Animal Diseases. Experimental and Molecular Pathology, 93, 116-128. https://doi.org/10.1016/j.yexmp.2012.04.017

[46] Aquilino, M., Masia, M., López, P., Galiana, A.J., Tovar, J., Andrés, M. and Gutiérrez, F. (2015) First Human Systemic Infection Caused by Spiroplasma. Journal of Clinical Microbiology, 53, 719-721. https://doi.org/10.1128/JCM.02841-14

[47] Almuzara, M.N., Palombarani, S., Tuduri, A., Figueroa, S., Gianecini, A., Sabater, L., Ramirez, M.S. and Vay, C.A. (2011) First Case of Fulminant Sepsis Due to Wohlfahrtiimonas chitiniclastica. Journal of Clinical Microbiology, 49, 2333-2335. https://doi.org/10.1128/JCM.00001-11

[48] Johler, S., Kalbhenn, E.M., Heini, N., Brodmann, P., Gautsch, S., Bagcioglu, M., Contzen, M., Stephan, R. and Ehling-Schulz, M. (2018) Enterotoxin Production of Bacillus thuringiensis Isolates From Biopesticides, Foods, and Outbreaks. Frontiers in Microbiology, 9, 1915. https://doi.org/10.3389/fmicb.2018.01915

[49] Klunder, H.C., Wolkers-Rooijackers, J., Korpela, J.M. and Nout, M.J.R. (2012) Microbiological Aspects of Processing and Storage of Edible Insects. Food Control, 26, 
628-631. https://doi.org/10.1016/j.foodcont.2012.02.013

[50] Vandeweyer, D., Wynants, E., Crauwels, S., Verreth, C., Viaene, N., Claes, J., Lievens, B. and Van Campenhout, L. (2018) Microbial Dynamics during Industrial Rearing, Processing and Storage of the Tropical House Cricket for Human Consumption. Applied and Environmental Microbiology, 84, e00255-18. https://doi.org/10.1128/AEM.00255-18

[51] Nederlandse Voedsel and Ware Authoriteit (NVWA) Netherlands Food and Consumer Product Safety Authority (2014) Advisory Report on the Risk Associated with the Consumption of Mass-Reared Insects.

https://www.researchgate.net/publication/277716517_Advisory_report_on_the_risk s_associated_with_the_consumption_of_mass_reared_insects

[52] Federal Agency for the Safety of the Food Chain (FASFC) (2014).

http://www.afsca.be/scientificcommittee/opinions/2014/_documents/Advice14-201

4_ENG_DOSSIER2014-04.pdf

[53] Garofalo, C., Osimani, A., Milanović, V., Taccari, M., Aquilanti, L. and Clementi, F. (2015) The Occurrence of Beer Spoilage Lactic Acid Bacteria in Craft Beer Production. Journal of Food Science, 80, M2845-M2852. https://doi.org/10.1111/1750-3841.13112

[54] Pilet, M.F., Magras, C. and Federighi, M. (2005) Bactéries lactiques. In: Federighi, M., Ed., Manuel de bactériologie alimentaire, Polytechnica, Paris, 219-242.

[55] Murefu, T.R., Macheka, L., Musundire, R. and Manditsera, F.A. (2019) Safety of Wild Harvested and Reared Edible Insects: A Review. Food Control, 101, 209-224. https://doi.org/10.1016/j.foodcont.2019.03.003

[56] Van der Fels-Klerx, H.J., Camenzuli, L., Belluco, S., Meijer, N. and Ricci, A. (2018) Food Safety Issues Related to Uses of Insects for Feeds and Foods. Comprehensive Review of Food Science and Food Safety, 17, 1172-1183. https://doi.org/10.1111/1541-4337.12385

[57] Stoops, J., Vandeweyer, D., Crauwels, S., Verreth, C., Boeckx, H., Van der Borght, M., Claes, J., Lievens, B. and Van Campenhout, L. (2017) Minced Meat-Like Products from Mealworm Larvae (Tenebrio molitor and Alphitobius diaperinus): Microbial Dynamics during Production and Storage. Innovative Food Science and Emerging Technology, 41, 1-9. https://doi.org/10.1016/j.ifset.2017.02.001

[58] Rumpold, B.A., Fröhlinga, A., Reineke, K., Knorr, D., Boguslawski, S., Ehlbeck, J. and Schlüter, O.K. (2014) Comparison of Volumetric and Surface Decontamination Techniques for Innovative Processing of Mealworm Larvae (Tenebrio molitor). Innovative Food Science and Emerging Technology, 26, 232-241. https://doi.org/10.1016/j.ifset.2014.09.002

[59] Chomchai, S. and Chomchai, C. (2018) Histamine Poisoning from Insect Consumption: An Outbreak Investigation from Thailand. Clinical Toxicology, 56, 126-131. https://doi.org/10.1080/15563650.2017.1349320

[60] Stoops, J., Crauwels, S., Waud, M., Claes, J., Lievens, B. and Van Campenhout, L. (2016) Microbial Community Assessment of Mealworm Larvae (Tenebrio molitor) and Grasshoppers (Locusta migratoria migratorioides) Sold for Human Consumption. Food Microbiology, 53, 122-127.

https://doi.org/10.1016/j.fm.2015.09.010

[61] Grabowski, N.T. and Klein, G. (2017) Microbiological Analysis of Raw Edible Insects Journal of Insects for Food and Feed, 3, 7-14. https://doi.org/10.3920/JIFF2016.0004

[62] Vandeweyer, D., Crauwels, S., Lievens, B. and Van Campenhout, L. (2017) Metage- 
netic Analysis of the Bacterial Communities of Edible Insects from Diverse Production Cycles at Industrial Rearing Companies. International Journal of Food Microbiology, 261, 11-18. https://doi.org/10.1016/j.ijfoodmicro.2017.08.018

[63] Vandeweyer, D., Crauwels, S., Lievens, B. and Van Campenhout, L. (2017) Microbial Counts of Mealworm Larvae (Tenebrio molitor) and Crickets (Acheta domesticus and Gryllodes sigillatus) from Different Rearing Companies and Different Production Batches. International Journal of Food Microbiology, 242, 13-18. https://doi.org/10.1016/j.ijfoodmicro.2016.11.007

[64] Caparros Megido, R., Desmedt, S., Blecker, C., Béra, F., Haubruge, E., Alabi, T. and Francis, F. (2017) Microbiological Load of Edible Insects Found in Belgium. Insects, 8, 12. https://doi.org/10.3390/insects8010012

[65] Garofalo, C., Osimani, A., Milanovic, V., Taccari, M., Cardinali, F., Aquilanti, L., Riolo, P., Ruschioni, S., Isidoro, N. and Clementi, F. (2017) The Microbiota of Marketed Processed Edible Insects as Revealed by High-Throughput Sequencing. Food Microbiology, 62, 15-22. https://doi.org/10.1016/j.fm.2016.09.012

[66] Wynants, E., Crauwels, S., Lievens, B., Luca, S., Claes, J., Borremans, A., Bruyninckx, L. and Van Campenhout, L. (2017) Effect of Post-Harvest Starvation and Rinsing on the Microbial Numbers and the Bacterial Community Composition of Mealworm Larvae (Tenebrio molitor). Innovative Food Science and Emerging Technology, 42, 8-15. https://doi.org/10.1016/j.ifset.2017.06.004

[67] Osimani, A., Milanović, V., Garofalo, C., Cardinali, F., Roncolini, A., Sabbatini, R., De Filippis, F., Ercolini, D., Gabucci, C., Petruzelli, A., Tonucci, F., Clementi, F. and Aquilanti, L. (2018) Revealing the Microbiota of Marketed Edible Insects through PCR-DGGE, Metagenomic Sequencing and Real-Time PCR. International Journal of Food Microbiology, 276, 54-62. https://doi.org/10.1016/j.ijfoodmicro.2018.04.013

[68] Fasolato, L., Cardazzo, B., Carraro, L., Fontana, F., Novelli, E. and Balzan, S. (2018) Edible Processed Insects from e-Commerce: Food Safety with a Focus on the Bacillus cereus Group. Food Microbiology, 76, 296-303. https://doi.org/10.1016/j.fm.2018.06.008

[69] Messaoudi, M., Manai, M., Federighi, M. and Dousset, X. (2013) Campylobacter in Poultry: Bibliographic Study on Control Strategies at the Breeding Step. Revue de Médecine Vétérinaire, 164, 90-99.

[70] Belluco, S., Losasso, C., Maggioletti, M., Alonzi, C.C., Ricci, A. and Paoletti, M.G. (2015) Edible Insects: A Food Security Solution or a Food Safety Concern? Animal Frontiers, 5, 25-30.

[71] Ssepuuya, G., Wynants, E., Verreth, C., Crauwels, S., Lievens, B., Claes, J., Nakimbugwe, D. and Van Campenhout, L. (2019) Microbial Characterisation of the Edible Grasshopper Ruspolia differens in Raw Condition after Wild-Harvesting in Uganda. Food Microbiology, 77, 106-117. https://doi.org/10.1016/j.fm.2018.09.005

[72] Grabowski, N.T. and Klein, G. (2017) Bacteria Encountered in Raw Insect, Spider, Scorpion, and Centipede Taxa Including Edible Species, and Their Significance from the Foodhygiene Point of View. Trends in Food Science and Technology, 63, 80-90. https://doi.org/10.1016/j.tifs.2017.01.007

[73] Ali, A., Mohamadou, B.A., Saidou, C., Aoudou, Y. and Tchiegang, C. (2010) Physicochemical Properties and Safety of Grasshoppers, Important Contributors to Food Security in the Far North Region of Cameroon. Research Journal of Animal Sciences, 4, 108-111. https://doi.org/10.3923/rjnasci.2010.108.111

[74] Wynants, E., Crauwels, S., Verreth, C., Gianotten, N., Lievens, B., Claes, J. and Van Campenhout, L. (2019) Risks Related to the Presence of Salmonella sp. during 
Rearing of Mealworms (Tenebrio molitor) for Food and Feed: Survival in the Substrate and Transmission to the Larvae. Food Control, 100, 227-234. https://doi.org/10.1016/j.foodcont.2019.01.026

[75] Walia, K., Kapoor, A. and Farber, J.M. (2018) Qualitative Risk Assessment of Cricket Powder to Be Used to Treat Undernutrition in Infants and Children in Cambodia. Food Control, 92, 169-182. https://doi.org/10.1016/j.foodcont.2018.04.047

[76] Banjo, A.D., Lawal, O.A. and Adeyemi, A.I. (2006) The Microbial Fauna Associated with the Larvae of Oryctes monocerus. Journal of Applied Science Research, 2, 837-843.

[77] Braide, W., Oranusi, S., Udegbunam, L.I., Oguoma, O., Akobondu, C. and Nwaoguikpe, R.N. (2011) Microbiological Quality of an Edible Caterpillar of an Emperor Moth, Bunaea alcinoe. Journal of Ecology and the Natural Environment, 3, 176-180.

[78] Opara, M.N., Sanyigha, F.T., Ogbuewu, I.P. and Okoli, I.C. (2012) Studies on the Production Trend and Quality Characteristics of Palm Grubs in the Tropical Rainforest Zone of Nigeria. Journal of Agricultural Technology, 8, 851-860.

[79] Ekrakene, T. and Igeleke, C.L. (2007) Microbial Isolates from the Roasted Larva of the Palm Weevil (Rhynchophorus phoenicis) from Edo and Delta States of Nigeria. Australian Journal of Basic and Applied Science, 1, 763-768.

[80] Braide, W., Nwaoguikpe, R.N., Oranusi, E., Udegbunam, L.I., Akobondu, C. and Okorondus, S.I. (2011) The Effect of Biodeterioration on the Nutritional Composition and Microbiology of an Edible Long-Winged Reproductive Termite, Macroterms bellicosus Smeathman. Internet Journal of Food Safety, 13, 107-114.

[81] Ebenebe, C.I. and Okpoko, V.A. (2015) Microbiological Quality of Raw and Roasted African Palm Weevil (Rhynchophorus phoenicis) Consumed in the South Eastern Nigeria. Animal Research International, 12, 2159-2165.

[82] Milanović, V., Osimani, A., Pasquini, M., Aquilanti, L., Garofalo, C., Taccari, M., Cardinali, F., Riolo, P. and Clementi, F. (2016) Getting Insight into the Prevalence of Antibiotic Resistance Genes in Specimens of Marketed Edible Insects. International Journal of Food Microbiology, 227, 22-28. https://doi.org/10.1016/j.ijfoodmicro.2016.03.018

[83] Osimani, A., Cardinali, F., Aquilanti, L., Garofalo, C., Roncolini, A., Milanović, V., Pasquini, M., Tavoletti, S. and Clementi, F. (2017) Occurrence of Transferable Antibiotic Resistances in Commercialized Ready-to-Eat Mealworms (Tenebrio molitor L.). International Journal of Food Microbiology, 263, 38-46. https://doi.org/10.1016/j.ijfoodmicro.2017.10.009

[84] Milanović, V., Osimani, A., Roncolini, A., Garofalo, C., Aquilanti, L., Pasquini, M., Tavoletti, S., Vignaroli, C., Canonico, L., Ciani, M. and Clementi, F. (2018) Investigation of the Dominant Microbiota in Ready-to-Eat Grasshoppers and Mealworms and Quantification of Carbapenem Resistance Genes by qPCR. Froniers in Microbiology, 9, 3036. https://doi.org/10.3389/fmicb.2018.03036

[85] Osimani, A., Garofalo, C., Aquilanti, L., Milanović, V., Cardinali, F., Taccari, M., Pasquini, M., Tavoletti, S. and Clementi, F. (2017) Transferable Antibiotic Resistances in Marketed Edible Grasshoppers (Locusta migratoria migratorioides). Journal of Food Science, 82, 1184-1192. https://doi.org/10.1111/1750-3841.13700

[86] Vandeweyer, D., Milanović, V., Garofalo, C., Osimani, A., Clementi, F., Van Campenhout, L. and Aquilanti, L. (2019) Real-Time PCR Detection and Quantification of Selected Transferable Antibiotic Resistance Genes in Fresh Edible Insects from Belgium and the Netherlands. International Journal of Food Microbiology, 290, 
288-295. https://doi.org/10.1016/j.ijfoodmicro.2018.10.027

[87] Yen, A.L. (2010) Edible Insects and Other Invertebrates in Australia: Future Prospects. In: Durst, P.B., Johnson, D.V. and Leslie, R.N., Eds., Edible Forest Insect: Human Bite Back. Proceedings of a Workshop on Asia-Pacific Resources and Their Potential for Development, Bangkok, 65-84.

[88] Van Huis, A. (2013) Potential of Insects as Food and Feed in Assuring Food Security. Annual Review of Entomology, 58, 563-583. https://doi.org/10.1146/annurev-ento-120811-153704

[89] Mpuchane, S., Gashe, B.A., Allotey, J., Siame, B., Teferra, G. and Ditlhogo, M. (2000) Quality Deterioration of Phane, the Edible Caterpillar of an Emperor Moth Imbrasia belina. Food Control, 11, 453-458. https://doi.org/10.1016/S0956-7135(00)00010-4

[90] Federighi, M. (2015) HACCP Method: A Practical Approach. Techniques de l'Ingénieur, November, 1-16.

https://www.techniques-ingenieur.fr/base-documentaire/mesures-analyses-th $1 / \mathrm{secu}$ $\underline{\text { rite-au-laboratoire-42378210/methode-haccp-approche-pragmatique-sl6210/ }}$

\section{Abbreviation List}

BT: Bacillus Thuringiensis

CFU: Colony Forming Unit

$\mathrm{CI}$ : Confidence Interval

HACCP: Hazard Analysis Critical Control Point

ID50: Infectious Dose 50

LAB: Lactic Acid Bacteria

MPN: Most Probable Number

OTU: Operational Taxonomic Unit

QMP: Quality Management Program

RR: Risk Ratio or Related Risk

rRNA: ribosomal RiboNucleic Acid

STEC: Shiga Toxin Escherichia coli

TMA: Total Mesophilic Aerobes

TAC: Total Aerobic Count 